DOI: 10.17707/AgricultForest.63.4.05

\author{
Marga GRADILA, Daniel JALOBA ${ }^{I}$
}

\title{
CONTROL OF A PROBLEMATIC WEED Sorghum halepense FROM MAIZE CROPS IN ROMANIA
}

\begin{abstract}
SUMMARY
Romania has one of the highest degrees of infestation with Sorghum halepense because this weed is a thermophilic and heliophilous species. It found satisfactory growth and development conditions due to the high fertility of soils, especially under the conditions of substantial underground water intake. Maize is one of the very sensitive crop plants to infestation with Sorgum halepense especially in the early stages of development. The only effective way to control this weed is to use selective herbicides for maize crops having aggressive action on this weed. The aim of this study was the control of Sorghum halepense from seeds and rhizomes by post-emergence application of nicosulphuron-based herbicides in various doses and different development stages of weeds in maize crop. The experiments were carried out in Afumati farm, Ilfov County, in two years 2015 and 2016, and they were placed in randomized blocks and the observations targeted the degree of effectiveness in controlling weeds and crop selectivity. The herbicides based on nicosulphuron had a good efficacy in controlling Sorghum halepense in maize crops. At the dose of $1.0 \mathrm{lha}^{-1}$ this weed was not fully controlled, in conditions of strong infestation. The best results were obtained at the dose of $1.5 \mathrm{lha}^{-1}$ applied in sequential treatments. Also, no phytotoxic symptoms were shown in experimental fields.
\end{abstract}

Keywords: control, herbicide, nicosulphuron, weeds.

\section{INTRODUCTION}

Regardless of the historical stage and maize (Zea mays) cultivation system, the highest costs in the production process are with weeds control. By its biology nature, corn plants are characterized as lacking the ability to compete with weeds, especially in the early stages of vegetation. Slow growth of corn plants in the first 4-6 weeks after emergence, associated with a low density (4-6 plant $/ \mathrm{m}^{2}$ ), creates a major advantage in the competition since the beginning in favor of weeds (Ghosheh et al., 1996, Torma et al., 2006). Herbicidation is one of the most important methods for weed control in maize crops. Perennials are difficult to control because they regenerate after application of agro-technical methods and also after application of herbicides. The importance of these weeds (Sorghum halepense, Elymus repens) in maize crops increased during last years and it

\footnotetext{
${ }^{1}$ Marga Gradila (corresponding author: marga_gradila@yahoo.com), Daniel Jaloba Research Development Institute for Plant Protection, Bucharest, ROMANIA.

Paper presented at the 8th International Scientific Agricultural Symposium "AGROSYM 2017".

Notes: The authors declare that they have no conflicts of interest. Authorship Form signed online.
} 
requires new control strategies. Weeds by their number, by rapacity for space, water and food, through the presence of diseases and pests common to crop plants, are causing great damage to maize crops. Depending on the degree of weed infestation, the damage varies between $30-80 \%$ of the production obtained, and in case of infestation with species Sorghum halepense from rhizomes sometimes can reach to total compromise of the crop (Sarpe et al., 1976, Chirila, 2001, Berca 1996, 2004). In this context, the paper presents data on the efficacy of nicosulphuron, sulfonylurea-base herbicides, in control of Sorgum halepense an invasive species in maize crops of Romania, aiming to improve agricultural technology and obtaining better crops.

\section{MATERIAL AND METHODS}

The experiments were placed at SC Agricola Afumati, Ilfov, Romania, in randomized blocks, in 4 repetitions with plot area of $30 \mathrm{~m}^{2}$ on loamy clay soil with a $\mathrm{pH}$ of 6.5 and an organic matter content of $2.5 \%$. Each experimental block included an untreated and a standard reference. Nicosulfuron-based herbicides were applied post emergently in a dose of 1.0 and 1.5 ha- 1 in one treatment, and in 2 sequential treatments - the first treatment (A) with 0.75 lha- 1 when millet was on the stage of four leaves and the second (B) 10 days after the first treatment with 0.75 lha-1 when millet was on the stage of eight leaves. Weed density was assessed in ground \% and in plants number on square meter. Weed control (efficacy) was assessed at 10, 28, 42 days after each application in \% control comparative with untreated. Also, were performed observations on the weeds present in the experimental plots before treatment, and selectivity - at each date of the efficacy assessments. Determination of segetal flora was performed on a square meter using a metric frame. Statistical preparation of the results was based on the analysis of ARM-9 ( $\mathrm{P}=.05$, Student-Newman-Keuls).

\section{RESULTS AND DISCUSSION}

Maize, the main cultivated plant in Romanian agriculture, shows a strong and diversified infestation with monocotyledonous and dicotyledonous annual and perennial weeds. The agriculture practiced in recent years has led to changes in the structure and frequency of weeds in maize both quantitatively and especially qualitatively. Grass weed species have become more damaging than dicotyledonous, with an increasing frequency of Sorghum halepense, Echinochloa crus-galli, Setaria spp., and Elymus repens. Romania has one of the highest degrees of infestation with $S$. halepense. S. halepense is a thermophilic and heliophilous species that finds satisfactory growth and development conditions in Romania due to the high fertility of soils, especially under the conditions of substantial underground water intake. The large number of seeds (2000-5000 per plant) produced by each plant as well as the extensive rhizome system make this weed to be difficult to combat. The rhizomes grow vertically in depth, reaching 1.5-2.0 $\mathrm{m}$ in the soil, which gives them great drought resistance. The rhizome internodes have an average length of $1.3-3.5 \mathrm{~cm}$. From 1 to $10 \mathrm{~kg}$ of 
rhizomes with 500-2000 buds could be found on an area of $1 \mathrm{~m} 2$. Primary rhizomes appear when the sorghum plant forms the 4th leaf. They will generate the secondary rhizomes which will form the aerial part of the plant. Reserve rhizomes appear during flowering period and they will generate, in the very next year, the aerial part of the plant. The rhizome segments resulting from soil work are able to form a new sorghum plant even if they have a single node, especially if it is at a depth of $15 \mathrm{~cm}$ (Anghel et al., 1972). The plant height of 1.0-1.5 m allows it to shade the surrounding plants, thus reducing the amount of water and nutrients available to the crop (Monaghan, 1979, Maurer et al., 1987, Camacho et al., 1991, Vitta and Leguizamon, 1991, Chirila, 2001). Maximum sensitivity toward infestation with $S$. halepense manifests itself in the early stages of vegetation. The predominant species identified in the studied locations were: $S$. halepense, but in the experimental field were present also other weed species: Echinochloa crus-galli and Setaria spp., Amaranthus retroflexus, Convolvulus arvensis, Xanthium italicum, Solanum nigrum, but with a low density.

The growth stages majority of Zea mays and Sorghum halepense at each assessment is presented in table 1.

Table 1. Growth stage of Zea mays and Sorghum halepense

\begin{tabular}{|c|c|c|}
\hline Plants & BBCH & Description \\
\hline \multirow{4}{*}{ Zea mays } & ${ }^{\text {st }}$ assessment 16 & 6 leaves unfolded \\
\cline { 2 - 3 } & $2^{\text {nd }}$ assessment 18 & 8 leaves unfolded \\
\cline { 2 - 3 } & $3^{\text {rd }}$ assessment 39 & $\begin{array}{c}\text { Flag leaf stage: flag leaf fully unrolled, } \\
\text { ligule just visible }\end{array}$ \\
\cline { 2 - 3 } & $4^{\text {th }}$ assessment 51 & $\begin{array}{c}\text { Beginning of tassel emergence: tassel } \\
\text { detectable at tip of stem }\end{array}$ \\
\cline { 2 - 4 } & $5^{\text {th }}$ assessment 55 & $\begin{array}{c}\text { Middle of tassel emergence, middle of tase } \\
\text { begins to separate }\end{array}$ \\
\hline \multirow{4}{*}{$\begin{array}{c}\text { Sorghum } \\
\text { halepense }\end{array}$} & $1^{\text {st }}$ assessment 14 & 4 leaves unfolded \\
\cline { 2 - 4 } & $2^{\text {nd }}$ assessment 18 & 8 leaves unfolded \\
\cline { 2 - 3 } & $3^{\text {rd }}$ assessment 48 & $\begin{array}{c}\text { Constant new development of young } \\
\text { plants-vegetative reproductive organs reach } \\
\text { final size }\end{array}$ \\
\cline { 2 - 3 } & $4^{\text {th }}$ assessment 55 & First individual flowers visible (still closed) \\
\cline { 2 - 3 } & $5^{\text {th }}$ assessment 67 & $\begin{array}{c}\text { Flowering finishing: majority of petals } \\
\text { fallen or dry }\end{array}$ \\
\hline
\end{tabular}

Coverage with species $S$. halepense in the experimental field was high: $45.5 \%$ before treatment application $61.3 \%$ at 14 days, $66.8 \%$ at 28 days and over $70.0 \%$ at 42 days after treatment application. In these conditions of weed infestation, a solution for avoiding harvest losses is the post-emergence application of herbicides with the following advantages: removes pre-emergence application of herbicides which under drought conditions becomes useless, 
doesn't require incorporation, reduces the number of treatments and the cost on hectar, low fuel consumption, flexibility in application time depending on degree of weeding. Following the observations we carried out, it has been assessed that this herb's success is due to the plant's subterranean part which is formed by rhizomes and the supplementary roots. During our observations we have identified plants with roots that achieved over 2.50 meters depth in the soil, this allowing indeed a greater tolerance to drought. Rhizomes are another biological feature, as the present lengths of over $25 \mathrm{~cm}$ and thickness of over $3 \mathrm{~cm}$, they form more rapidly knots and inter-knots by which $S$. halepense is being multiplied, determining a large number of tillers per plant.

Table 2. Density of weed in maize crop before treatments

\begin{tabular}{|c|c|c|c|c|c|c|}
\hline \multirow{3}{*}{ Variant } & \multirow{3}{*}{$\begin{array}{l}\text { Dose } \\
\text { f.p. }{ }^{1} \\
\text { (1/ha) }\end{array}$} & \multirow{3}{*}{$\begin{array}{l}\text { Dose } \\
\text { a.i. }{ }^{2} \\
\text { g/ha }\end{array}$} & \multicolumn{2}{|c|}{ Treatment A } & \multicolumn{2}{|c|}{ Treatment B } \\
\hline & & & \multicolumn{4}{|c|}{ Density } \\
\hline & & & $\begin{array}{l}\text { Coupla } \\
/ \mathrm{m}^{2}\end{array}$ & $\begin{array}{c}\text { Ground } \\
(\%)\end{array}$ & $\begin{array}{l}\text { Coupla } \\
/ \mathrm{m}^{2}\end{array}$ & $\begin{array}{l}\text { Ground } \\
(\%)\end{array}$ \\
\hline untreated & - & - & 38.5 & 45.5 & 53.3 & 61.3 \\
\hline \multirow{3}{*}{ nicosulphuron } & 1.0 & 60 & 27.5 & 33.0 & - & - \\
\hline & 1.5 & 90 & 28.3 & 33.8 & - & - \\
\hline & $0.75+0.75$ & $45+45$ & 25.0 & 33.0 & 1.0 & 1.5 . \\
\hline $\begin{array}{l}\text { standard } \\
\text { reference }\end{array}$ & 1.5 & 90 & 28.3 & 33.0 & 0.5 & 1.0 \\
\hline \multicolumn{2}{|c|}{$\operatorname{LSD}(\mathrm{P}=.05)$} & & 5.30 & 5.99 & 1.73 & 2.1 \\
\hline \multicolumn{2}{|c|}{ Standard Deviation } & & 3.52 & 3.99 & 1.00 & 1.45 \\
\hline
\end{tabular}

${ }^{1}$ f.p. $=$ Formulated product/ha

${ }^{2}$ a.i.= Active ingredient/ha

Table 3.The efficacy of herbicide in maize crop after 10 days of treatments

\begin{tabular}{|c|c|c|c|c|c|c|}
\hline \multirow{3}{*}{ Variant } & \multirow{3}{*}{$\begin{array}{l}\text { Dose } \\
\text { (1/ha) }\end{array}$} & \multirow{3}{*}{ Appl. } & \multicolumn{2}{|c|}{ Treatment A } & \multicolumn{2}{|c|}{ Treatment B } \\
\hline & & & \multicolumn{4}{|c|}{ Efficacy } \\
\hline & & & $\begin{array}{c}\text { Dens. }^{1} \\
(\%)\end{array}$ & $\begin{array}{l}\text { E. }^{2} \\
(\%)\end{array}$ & $\begin{array}{c}\text { Dens. } \\
(\%)\end{array}$ & $\begin{array}{l}\text { E. } \\
(\%)\end{array}$ \\
\hline untreated & - & - & 61.3 & - & 63.8 & - \\
\hline \multirow{3}{*}{ nicosulphuron } & 1.0 & A & 1.5 & 97.3 & - & - \\
\hline & 1.5 & A & 0.0 & 100 & - & - \\
\hline & $0.75+0.75$ & $A+B$ & 1.0 & 98.0 & 0.0 & 100 \\
\hline $\begin{array}{l}\text { standard } \\
\text { reference }\end{array}$ & 1.5 & A & 0.0 & 100 & 0.0 & 100 \\
\hline \multicolumn{3}{|c|}{ LSD $(\mathrm{P}=.05)$} & 1.55 & 2.87 & . & . \\
\hline \multicolumn{3}{|c|}{ Standard Deviation } & 1.03 & 1.90 & 0.00 & 0.00 \\
\hline
\end{tabular}

${ }^{1}$ Dens. = density $($ ground $\%)$

${ }^{2} \mathrm{E} .=$ efficacy $($ control \%) 
The nicosulphuron, sulfonylurea-based herbicide had a good efficacy in control of $S$. halepense weed in maize. At 10 days after treatment A the herbicide had a very good efficacy in control of $S$. halepense $98.0 \%$ at a dose of $1.5 \mathrm{Lha}^{-1}$ and $97.3 \%$ at $1.0 \mathrm{lha}^{-1}$, the results being similar to those of the standard reference (Table 3 ).

Nicosulphuron applied in postemergence is quickly absorbed by weeds mainly through the leaves and roots, is then translocated into the sap stream to the apical meristems, where they cause irreversible disturbances in cell division. The total control of weeds is carried out in a longer period of up to three weeks. The weed ceases to grow immediately after treatment.

Table 4.The efficacy of herbicide in maize crop after 28 days of treatments

\begin{tabular}{|c|c|c|c|c|c|c|}
\hline \multirow{3}{*}{ Variant } & \multirow{3}{*}{$\begin{array}{l}\text { Dose } \\
\text { (1/ha) }\end{array}$} & \multirow{3}{*}{ Appl. } & \multicolumn{2}{|c|}{ Treatment A } & \multicolumn{2}{|c|}{ Treatment B } \\
\hline & & & \multicolumn{4}{|c|}{ Efficacy } \\
\hline & & & $\begin{array}{c}\text { Dens. } \\
(\%)\end{array}$ & $\begin{array}{c}\mathrm{E} . \\
(\%)\end{array}$ & $\begin{array}{c}\text { Dens. } \\
(\%)\end{array}$ & $\begin{array}{l}\mathrm{E} . \\
(\%)\end{array}$ \\
\hline untreated & - & - & 66.8 & - & 68.0 & - \\
\hline \multirow[b]{3}{*}{ nicosulphuron } & 1.0 & A & 9.0 & 90.0 & - & - \\
\hline & 1.5 & A & 3.0 & 97.3 & - & - \\
\hline & $\begin{array}{c}0.75+0.7 \\
5\end{array}$ & $\mathrm{~A}+\mathrm{B}$ & 0.0 & 100 & 0.0 & 100 \\
\hline $\begin{array}{l}\text { standard } \\
\text { reference }\end{array}$ & 1.5 & A & 5.5 & 94.8 & 0.0 & 100 \\
\hline \multicolumn{3}{|c|}{$\operatorname{LSD}(\mathrm{P}=.05)$} & 2.91 & 3.74 & . & . \\
\hline \multicolumn{3}{|c|}{ Standard Deviation } & 2.01 & 2.59 & 0.00 & 0.00 \\
\hline
\end{tabular}

Table 5.The efficacy in maize crop of herbicides after 42 days of treatments

\begin{tabular}{|c|c|c|c|c|c|c|}
\hline \multirow[b]{2}{*}{$\begin{array}{c}\text { Treatment } \\
\text { name }\end{array}$} & \multirow[b]{2}{*}{$\begin{array}{l}\text { Dose } \\
\text { (1./ha) }\end{array}$} & \multirow{2}{*}{$\begin{array}{c}\text { App } \\
1 . \\
\text { cod } \\
\text { e }\end{array}$} & \multicolumn{2}{|c|}{ Treatment A } & \multicolumn{2}{|c|}{ Treatment B } \\
\hline & & & $\begin{array}{l}\text { Dens. } \\
(\%)\end{array}$ & $\begin{array}{l}\mathrm{E} . \\
(\%)\end{array}$ & Dens. $(\%)$ & $\begin{array}{l}\text { E. } \\
(\%)\end{array}$ \\
\hline Untreated & - & - & 71.0 & 0.0 & 71.0 & 0.0 \\
\hline \multirow[b]{3}{*}{ nicosulphuron } & 1.0 & $\mathrm{~A}$ & 29.8 & 61.3 & - & - \\
\hline & 1.5 & A & 13.5 & 82.8 & - & - \\
\hline & $\begin{array}{c}0.75+ \\
0.75\end{array}$ & $\begin{array}{c}\mathrm{A}+ \\
\mathrm{B}\end{array}$ & 0.0 & 100 & 7.5 & 91.5 \\
\hline $\begin{array}{l}\text { Standard } \\
\text { reference }\end{array}$ & 1.5 & A & 9.5 & 88.8 & 12.0 & 85.8 \\
\hline \multicolumn{3}{|c|}{$\operatorname{LSD}(\mathrm{P}=.05)$} & 2.90 & 3.21 & 2.90 & 3.21 \\
\hline \multicolumn{3}{|c|}{ Standard Deviation } & 2.01 & 2.22 & 2.01 & 2.22 \\
\hline
\end{tabular}


Observations shows that the action of the herbicide is influenced by climatic conditions and vegetation at the time of application, absorption and translocation are more intense and faster when weeds have optimal growth conditions (light, heat, water, food) and thus the inhibitory effect is more complete. In order to fully penetrate into the plant, it is necessary that after treatment, the rainfall should not fall for a period of 4-5 hours. Subsequent observations ( 28 and 42 days after treatments) confirmed the good results of the nicosulphuron herbicide in control of $S$. halepense in maize crops (Tables 3 and 4). At the dose of $1.5 \mathrm{lha}^{-1}$, the effect of the herbicide was maintained throughout the growing season of maize but at the dose of $1.0 \mathrm{hha}^{-1}$ species $S$. halepense is not entirely controlled such as control rate decreased from $90.0 \%$ at 28 days to $61.3 \%$ at 42 days after treatment application. No phytotoxicity symptoms have been shown in the experimental plot. No symptoms of chlorosis, necrosis, leaf deformation, height reduction, distortion and delay at flowering in plots treated with herbicides nicosulphuron. Maize plants managed by its own mechanism to metabolize the active substance and convert it to biologically inactive compounds, so the majority of maize hybrids show no phytotoxicity symptoms. In treated plots, maize plants were more vigorous and taller and culture density was much higher compared to control plot (Figure 1).

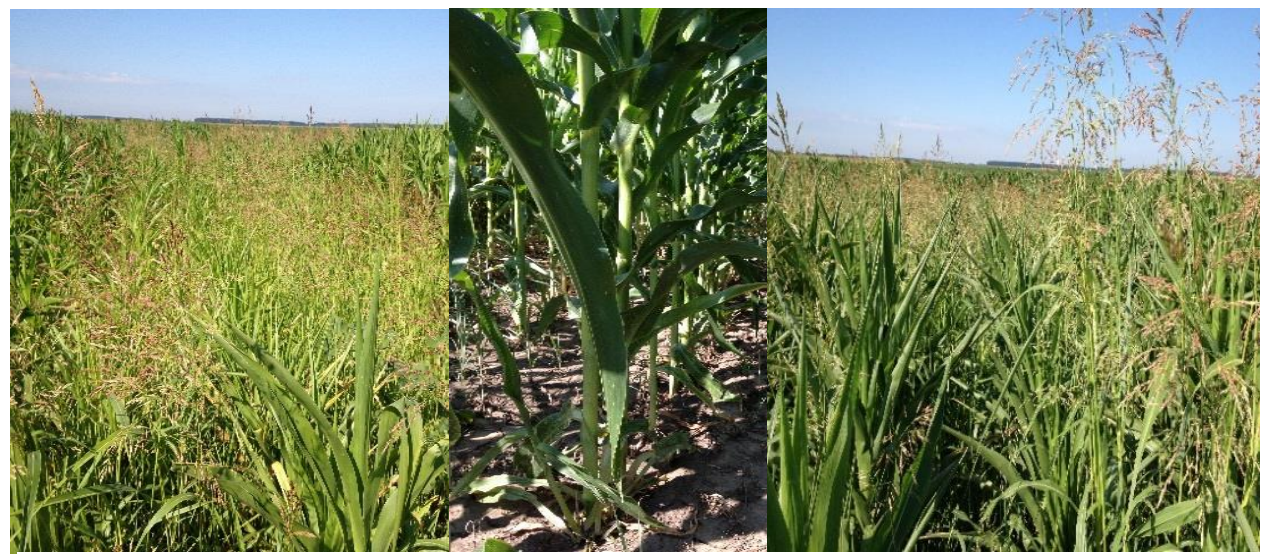

Figure 1. Aspects regarding of nicosulphuron efficacy after 42 days of treatment

\section{CONCLUSIONS}

The degree of weeds in maize crops was high, the predominant weed species was a perennial weed, S. halepense, with a coverage rate of over $70 \%$ at 42 days after treatment application.

Also annual monocotyledonous weed species Echinochloa crus-galli and Setaria spp. were present with low density percentage.

$S$. halepense is a problem weed for Romanian farmers, which find satisfactory growth and development conditions in Romania due to the high fertility of soils. 
The herbicide based on nicosulphuron had a good efficacy in controlling $S$. halepense in maize crops. The best results were obtained at the dose of $1.5 \mathrm{lha}^{-1}$ applied in sequential treatments the first treatment (A) with $0.75 \mathrm{lha}^{-1}$ when the millet would be on four leaves stage, and the second after 10 days after the first treatment (B) with 0.75 lha-1.

At the dose of 1.0 lha-1 S. halepense is not entirely controlled, in conditions of strong infestation. No phytotoxicity symptoms have been shown in experimental plots. No symptoms of chlorosis, necrosis, leaf deformation, height reduction, distortion and delay at flowering in plots treated with nicosulphuron.

In treated plots, maize plants were more vigorous and taller and culture density was much higher compared to control plot.

\section{REFERENCES}

Anghel GH., Chirila C., Ulinici A. (1972). Weeds in agricultural crops and control them. Ceres Publishing House, Bucharest.

Berca M. (1996). Weed control in crops. Fermierul Roman Publishing House, Bucharest.

Berca M. (2004). Integrated weed management. Ceres Publishing House, Bucharest.

Camacho Rolando F. et al. (1991). Rhizome johnsongrass (Sorghum halepense) control in corn (Zea mays) with primisulfuron and nicosulfuron. Weed Technology, vol. 5, pp. 789-794.

Chirila C. (2001). Weed biology. Ceres Publishing House, Bucharest.

Eleftherohorinos I.G., Kotoula-Syka E. (1995). Influence of herbicide application rate and timings for post-emergence control of Sorghum halepense (L.) Pers. maize. Weed Research, vol. 35, pp. 99-103.

Ghosheh H.Z., Holshouser D.L., Chandler J.M. (1996). The critical period of johnsongrass (Sorghum halepense) control in field corn (Zea mays). Weed Science, vol. 44, pp. 944-947.

Maurer W., Gerber H.R., Rufener J. (1987). CGA 136872 a new post-emergence herbicide for the selective control of Sorghum spp. and Elymus repens in maize. Proceedings British Crop Protection Conference-Weeds 9, 41-8.

Monaghan N. (1979). The biology of Johnson grass (Sorghum halepense). Weed Research, vol. 19, pp. 261-267.

Sarpe N., Ciorlaus A., Ghinea L., Vladutu I. (1976). Herbicides. Principles and Practice in weed control. Ceres Publishing House, Bucharest.

Vitta, J.I., Leguizamon E.S. (1991). Dynamics and control of Sorghum halepense (L.) Pers. shoot populations: a test of a thermal calendar model. Weed Research, vol. 31, pp. 73-79.

Torma M., Kazinczi, G., Hodi, L. (2006). Postemergence herbicide treatments in maize against difficult to control weeds in Hungary. Zeitschrift Fur Pflanzenkrankheiten Und Pflanzenschutz-Sonderheft, 20: 781. 